\title{
Application of Predialytic Exercise To Reduce Fatigue In-Patient Undergoing Hemodialysis
}

\section{Nugroho Lazuardi ${ }^{1,2}$}

1 Universitas Muhammadiyah Semarang, Indonesia

2 Tugurejo Hospital of Central Java Province, Ind onesia

\section{Article Info}

\section{Article History:}

Submit Feb 5th, 2021

Accepted March 1st, 2021

Published March 28th 2021

\section{Keywords:}

Predialytic exercise; Fatigue; Hemodialysis

\section{INTRODUCTION}

Chronic kidney disease (CKD) is an irreversible and slow disruption of kidney function therefore unable to maintain the body's metabolism, fluid, and electrolyte balance cause uremia which requires dialysis or kidney transplantation. There are 70,000 sufferers of CKD in Indonesia, and it will be increased every year by up to

\begin{abstract}
Chronic kidney disease is an irreversible and slow-progressing disorder of kidney function so that the kidneys are unable to maintain the body's metabolism, fluid and electrolyte balance and cause uremia which requires dialysis or kidney transplantation. Hemodialysis is management to treat chronic kidney disease that is carried out for life so that the complications that often arise are fatigue, cramps, anxiety, pain. The phenomenon found in the Hemodialysis Room of the Tugurejo Hospital Semarang, there were 34\% of the 84 patients who experienced fatigue which was characterized by lethargy, weakness, drowsiness, dizziness. This research is a quantitative study with a quasi-experimental design. The sample size is 4 respondents in the intervention group without a control group. Measurement of the level of fatigue (pre and post-test) using the PFS (Piper Fatigue Scale) which contains 22 subjective statements. Predialytic Exercise intervention is given for 5 sessions with a duration of 10-15 minutes. The results of this study indicate that the fatigue level of hemodialysis patients has decreased after the intervention of predialytic exercise for 5 sessions. The fatigue score of respondents 1 has decreased from a score of 4.8 (moderate fatigue) to 3.2 (mild fatigue), respondent 2 from a score of 6.3 (moderate fatigue) to 4.3 (moderate fatigue), respondent 3 from score 9 (severe fatigue) to 7 (severe fatigue), and respondent 1 from a score of 4.9 (moderate fatigue) to 2.4 (mild fatigue). The results of this study indicate that there is a decrease in each dimension of fatigue levels so that predialytic exercise intervention is effective to reduce fatigue in patients undergoing hemodialysis.
\end{abstract}

$10 \%$. Data from the Indonesian Ministry of Health (2017), 30,554 active patients were undergoing dialysis, 1,243 patients died with 1-317 months of HD time. Indonesian Renal Registry data (2016), states that as many as $98 \%$ of CKD sufferers undergo hemodialysis therapy and $2 \%$ of Peritoneal Dialysis (PD) therapy with the most common causes of CKD are diabetic nephropathy (52\%), hypertension (24\%). ${ }^{1,2}$

Corresponding author:

Nugroho Lazuardi

nugroho.lazuardi@unimus.ac.id

South East Asia Nursing Research, Vol 3 No 1, March 2021

ISSN:2685-032X

DOI: https://doi.org/10.26714/seanr.3.1.2021.28-32 
The majority of people with CKD need therapy in the form of hemodialysis. Hemodialysis is a process of cleansing the blood using an artificial kidney, namely a dialyzer with the goal is to maintain good nephron function, reduce morbidity, reduce uremia pericarditis, uremia encephalopathy, fluid overload, nutritional disorders, and infections, therefore, the quality of health and the quality of life among patients is improved. The hemodialysis process takes 4-5 hours generally will cause side effects such as physical stress, fatigue, headaches, cramps, and cold sweat due to decreased blood pressure and sugar levels. ${ }^{3,4}$

Fatigue is a feeling of excruciating characterized by a constant decrease in strength or physical and mental labor. Fatigue is a problem that is most often felt as a side effect of CKD sufferers undergoing hemodialysis which can cause physical, social, and psychological problems that interfere with daily activities and the patient's quality of life. Fatigue is caused by changes in health conditions, sleep disorders, psychological disorders and poor nutritional status. ${ }^{4-6}$

Non-pharmacological interventions that can be given to CKD patients with hemodialysis with fatigue are progressive Muscle relaxation, range of motion, and breathing exercises or predialysis Exercise. Predialytic exercise can be increasing blood flow, and the number of capillary areas in the muscles, so it can reduce the occurrence of complications such as fatigue, muscle cramps, and anxiety. ${ }^{6}$

Based on the explanation before, therefore, this study aims to determine the effect of predialytic exercise on the level of fatigue in patients undergoing hemodialysis at Tugurejo Hospital, Central Java, Indonesia. was used in this study. The population was patients with chronic kidney disease in the Hemodialysis Installation of Tugurejo Hospital, Central Java, Indonesia. Based on initial data, there were 86 patients who underwent hemodialysis as routinely.

The sampling technique is convenience sampling, where the researcher selects the sample at the study site according to the research criteria until the number of research samples is obtained. Patients who meet the criteria will be recruited as respondents.

This study uses the Piper Fatigue Scale (PFS) to measure the fatigue level of hemodialysis patients. PFS instrument can represent the subjective feelings of the respondents in expressing their fatigue. Data collection was carried out before and after being given for 5 meetings with a duration of 10-15 minutes.

This study was conducted by emphasizing the principles of research ethics including the consent form, anonymity, and confidentiality. Respondents who were willing and agreed become respondents were asked to fill out a questionnaire. Before treatment, respondents were explained. The univariate analysis aims to describe the characteristics and level of fatigue among respondents.

\section{RESULTS}

The implementation of the predialysis exercise in patients with chronic kidney disease in the Hemodialysis Unit of Tugurejo Regional Hospital was carried out from May 9, 2019, to May 23, 2019, with 4 patients as respondents who met the inclusion and exclusion criteria. The results of the research analysis are as follows:

\section{METHODS}

A quasi-experimental design on one group (intervention group) with pre and post-test 
Table 1

Frequency Distribution Characteristics of Respondents with Chronic Kidney Disease who Underwent Hemodialysis Semarang ( $\mathrm{n}=4)$

\begin{tabular}{lcc}
\hline \multicolumn{1}{c}{ Indicators } & f & \% \\
\hline Age & & \\
$\quad<30$ years old & & \\
$31-40$ years old & 1 & 25 \\
$\quad \begin{array}{l}41-50 \text { years old } \\
>50 \text { years old }\end{array}$ & 3 & 75 \\
\hline $\begin{array}{l}\text { Gender } \\
\quad \text { Male }\end{array}$ & & \\
$\quad$ Female & 4 & 100 \\
\hline
\end{tabular}

Education Level

Primary high School

Junior High School

Senior High School

$4 \quad 100$

Perguruan Tinggi

\begin{tabular}{lll}
\hline $\begin{array}{l}\text { Marital Status } \\
\quad \text { Unmarried }\end{array}$ & & \\
$\quad$ Married & 3 & 75 \\
$\quad$ Widow/Widower & 1 & 25 \\
\hline Length of & & \\
hemodialysis & & \\
$\quad<12$ month & 2 & 50 \\
$12-24$ month & 2 & 50 \\
$\quad>24$ month & & \\
\hline
\end{tabular}

Based on data on the characteristics of respondents (table 1 ), it shows that most (75\%) aged $>50$ years and all respondents are male and had a high school education level. As many as 3 respondents (75\%) are married and 1 respondent (25\%) are widowers, while for the duration of HD, 2 respondents (50\%) underwent 12-24 months of HD and 2 respondents (50\%) underwent $\mathrm{HD}>24$ months.

Respondents were given intervention in the form of predialysis exercise with a combination of progressive muscle relaxation movements, range of motion, and breathing exercise. The movements in this physical exercise are combined with the same principle of stretching and relaxing the muscles in the face, neck, shoulders, hands/arms, and legs. Exercises were given before the hemodialysis process started for 5 meetings on Monday and Thursday according to the respondent's schedule for hemodialysis. The duration of the intervention was 10-15 minutes with each movement of 8 beats and accompanied by music. For the first time doing this physical exercise, the respondents did not optimal in following the movements because they were afraid that they would cramp or make their muscles hurt and interfere with the hemodialysis process. The benefits of this physical exercise began to be felt after 3 times after undergoing routine interventions.

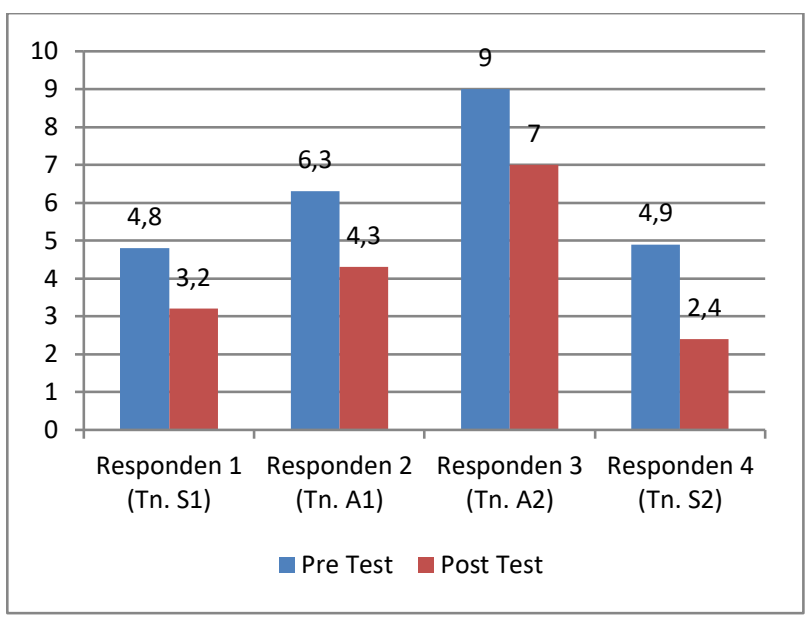

Figure 1

Frequency Distribution Score of Fatigue Level Before and After Predialytic Exercise

Figure 1 shows a decrease in the level of fatigue in the four respondents, where respondent 1 from a score of 4.8 (moderate fatigue) to 3.2 (mild fatigue). Respondent 2 from a score of 6.3 (moderate fatigue) to 4.3 (moderate fatigue). Respondent 3 from score 9 (severe fatigue) to 7 (severe fatigue). Respondent 4 from a score of 4.9 (moderate fatigue) to 2.4 (mild fatigue). The average fatigue score was 6.25 (moderate fatigue) in the pre-test and the average fatigue score was 4.25 (mild fatigue) in the post-test. The results showed that there was a decrease in the level of fatigue after being given the intervention of predialysis exercise (post-test) for 5 meetings, namely 2 respondents (50\%) had mild fatigue, 1 respondent $(25 \%)$ moderate fatigue, and 1 respondent (25\%) weight fatigue.

The value of the fatigue level before the intervention was carried out with a minimum fatigue level of 4.8 and a maximum of 9. Before being given the 
intervention, the respondents were in a fairly varied range of fatigue scores. There is one respondent with a score of fatigue 9, this is due to the age factor ( $>50$ years).

The subjective results obtained from the four respondents said that their body condition was better after HD was done and would have a maximum health status 1 day after HD, however, respondents would feel significantly tired after 2-3 days after HD. During HD, the four respondents said they prefer to use their time to sleep or close their eyes. Two respondents can sleep soundly during HD (1-2 hours) and two respondents can only close their eyes without sleeping soundly.

According to a statement from the respondent, the cause of the excessive fatigue because he was always feeling unhappy. He said he was not on good terms with his wife so when he was homemade he wants to be angry. He said that he was irritable and emotional. Another respondent said that the fatigue was due to not having much activity and that his feet were often swollen which interfered with his activities. The four respondents had poor sleep quality, indicated by sleep time that was only 3-4 hours a day, often waking up at night and having difficulty starting to sleep again, waking up sluggish is a factor that adds to fatigue.

\section{DISCUSSION}

The data showed that respondents' fatigue level was varied according to age. Age is a factor that can affect individual health. CKD sufferers who undergo HD age over 40 years are at risk of various complications that can interfere with the quality of life, including fatigue. Solomon's explained that the older a person is, the physical condition will weak and lead to fatigue condition. ${ }^{7}$

Decreased physical condition at old age results in higher levels of fatigue. Fatigue appears as a result of various factors, including physiological factors (anaemia, malnutrition, uremia, hyperparathyroidism, inflammation) which arise from chronic kidney disease. ${ }^{8}$ Complaints of fatigue in patients undergoing hemodialysis due to many factors, including poor nutritional status, psychological disorders, changes in health conditions, and poor sleep disorders. ${ }^{4,9}$

This study showed that there was a decrease in the level of fatigue after being given the intervention of predialysis exercise (post-test) 5 times having mild fatigue levels. These results support a study that physical exercise is effective in reducing fatigue levels in chronic kidney disease patients undergoing hemodialysis. ${ }^{8}$ The benefits of physical exercise began to be felt by the respondents, especially from the fourth week onwards. At the beginning of the exercise, the average respondent said they were afraid to do physical exercise, for fear of interfering with the hemodialysis process.

Regular physical exercise can increase blood flow to the muscles, increase the number of capillaries and increase the area and surface of the capillaries, thereby increasing the movement of urea and toxins from the tissues to the vasculature which are then flowed to a dialyzer or hemodialysis machine. Physical exercise can also show improvements in body fitness, physiological function, agility, reducing levels of fatigue, agility and increasing muscle strength. ${ }^{8}$ This physical exercise is also able to relax respondents, improve overall circulation, and lower blood pressure. 6

Apart from physical exercise, internal and social motivation is also needed to support the survival of HD patients. Patients who do physical exercise are likely to experience fewer complications. ${ }^{10}$ Many of the patients whose hemodialysis process is delivered and awaited by the family make the patient comfortable. Lifestyle must also be maintained, especially fluid restrictions to reduce oedema of the extremities or 
pulmonary oedema so that heart and lung function is easier and reduce fatigue or shortness of breath. ${ }^{11}$

\section{CONCLUSION}

Predialysis exercise has a positive effect to decrease fatigue level for dialysis patients. Predialysis exercise can be applied in the hemodialysis unit to reduce the level of fatigue and may improve the quality of life. The initial measurement carried out on the first day before the intervention was moderate fatigue and the second measurement after 5 times given the intervention was decreased to mild fatigue. Hemodialysis nurses are expected to apply predialysis exercise as nursing care for decreasing the fatigue level of hemodialysis patients.

\section{ACKNOWLEDGMENTS}

We gratitude to all parties, responders and nurses at the Hemodialysis Installation at Tugurejo Hospital for helping the research process.

\section{CONFLICTS OF INTEREST}

Neither of the authors has any conflicts of interest that would bias the findings presented here.

\section{REFERENCES}

1. Kemenkes RI. Info datin ginjal. Situasi Penyakit Ginjal Kron. 2017;1-10.

2. Indonesian P, Registry R, Renal I, Indonesia PN, Kesehatan D, Kesehatan D, et al. Indonesian
Renal Registry 2016. 2016;1-46.

3. Lazuardi N. Pengaruh intervensi support group terhadap kualitas hidup pasien penyakit ginjal kronis yang menjalani hemodialisa. 2016;1-80.

4. Fari AI, Sofiani Y, Warongan AW, Kesehatan FI, Katolik U, Charitas M, et al. Efektifitas Progressive Muscle Relaxation (PMR) dan Relaxation Breathing Exercise (RBE) Terhadap Tingkat Fatigue dan Selfcare Pasien GGK. J Kesehat Saelmakers Perdana. 2019;2(1):99110.

5. Amini E, Goudarzi I, Masoudi R, Ahmadi A, Momeni A. Effect of progressive muscle relaxation and aerobic exercise on anxiety, sleep quality, and fatigue in patients with chronic renal failure undergoing hemodialysis. Int J Pharm Clin Res. 2016;8(12):1634-9.

6. Sakitri G. Pengaruh Intradialitic exercise terhadap fatique pasien Hemodialisis di RSUP Dr. Soeradji Tirtonegoro Klaten. Profesi (Profesional Islam Media Publ Penelit. 2017;15(1):64.

7. Sulaiman. Hubungan Lamanya Hemodialisis Dengan Fatigue Pada Pasien Gagal Ginjal Di Rs Pku Muhammadiyah Yogyakarta. Skripsi. 2015;1-11.

8. Nur Aini Dwi. Pengaruh Latihan Fisik Terhadap Fatique pada pasien Iintrahemodialisis di RSUD Tugurejo Semarang. 2015;2015.

9. Sakitri G. Pengaruh intradialytic exercise terhadap fatigue pasien hemodialisis di RSUP Dr. Soeradji Tirtonegoro Klaten. Profesi (Profesional Islam Media Publ Penelit. 2017;15(1):64.

10. Retno SD. Efektivitas latihan fisik selama hemodialisis terhadap peningkatan kekuatan otot pasien penyakit ginjal kronik di rumah sakit umum daerah kota semarang. 2014;98107.

11. Novitasari ACDD. Kepatuhan Pembatasan Asupan Cairan Terhadap Lama Menjalani. J Prodi Keperawatan Univ Aisyiyah Yogyakarta. 2014;8(1):104-12. 